\title{
PENERAPAN METODE PEMBELAJARAN DENGAN PERMAINAN BOLA GANTUNG BERANGKA UNTUK MENINGKATKAN GERAK DASAR ANAK USIA DINI DI KECAMATAN PANYINGKIRAN KABUPATEN MAJALENGKA
}

\author{
Udi Sahudi $^{1}$ dan Maya Nurhayati ${ }^{2}$ \\ Universitas Majalengka, Indonesia \\ udisahudi@unma.ac.id \& mayanurhayati@unma.ac.id
}

\begin{abstract}
ABSTRAK. Pendidikan usia dini dilakukan sebagai salah satu syarat pada jenjang pendidikan dasar. Terkait upaya meningkatkan kemampuan gerak dasar siswa maka pendidik khususnya pada jenjang pendidikan usia dini di harapkan mampu memfasilitasi peningkatan kemampuan anak dalam meningkatkan kemampuan gerak dasar. Penelitian ini dilakukan untuk mengembangkan pembelajaran berbasis permainan sebagai suatu alternatif dalam pembelajaran pendidikan jasmani khususnya peningkatan gerak dasar siswa. Permainan yang diterapakan adalah permainan bola gantung berangka. Metode penelitian yang digunakan adalah metode penelitian eksperimen. Dengan menggunakan sampel penelitian sebanyak 30 orang anak usia dini. Hasil penelitian Berdasarkan hasil penghitungan yang dilakukan peneliti diperoleh nilai Thitung sebesar 0.27 dan Ttabel sebesar 2,05. maka dari hasil penghitungan tersebut jelaslah bahwa hipotesis dalam penelitian ini adalah sebagai berikut: Terdapat pengaruh yang efektif dari penerapan permainan bola gantung berangka terhadap kemampuan gerak dasar anak usia dini di Kecamatan Panyingkiran Kabupaten Majalengka.. Dengan kata lain setelah melihat hasil penghitungan tersebut, maka dengan demikian hipotesis yang penulis ajukan diterima. Guru atau orang tua harus mendorong anak-anak untuk menghabiskan beberapa jam di lingkungan luar yang serba guna setiap hari untuk mempromosikan pengembangan kemampuan gerak dasar anak dengan cara bermain.
\end{abstract}

Kata Kunci: Pembelajaran Berbasis Permainan, Gerak Dasar Motorik, Bola Gantung Berangka

\section{Pendahuluan}

Pendidikan usia dini dilakukan sebagai salah satu syarat pada jenjang pendidikan dasar. Terkait upaya meningkatkan kemampuan gerak dasar siswa maka pendidik khususnya pada jenjang pendidikan usia dini di harapkan mampu memfasilitasi peningkatan kemampuan anak dalam gerak dasar. Gerak dasar menurut Sugiyanto dalam Pratomo (2010) menyatakan:"Gerak dasar fundamental adalah gerakan- gerakan dasar yang berkembangnya sejalan dengan pertumbuhan dan tingkat kematangan anak-anak". Dalam gerak dasar ini terdapat tiga pola gerak yaitu lokomotor, nonlokomotor serta manipulatif.

Hasil studi pendahuluan ditingkat sekolah untuk anak usia dini di Kecamatan Panyingkiran Kabupaten Majalengka menunjukan bahwa kegiatan belajar mengajar Pendidikan Jasmani (penjas) masih menerapkan model pembelajaran dengan metode senam ria solatum dan jalan-jalan di lingkungan sekitar, serta lempar dan tangkap bola untuk meningkatkan gerak 
dasar. Hal tersebut dianggap masih kurang efektif dan optimal dalam upaya meningkatkan kemampuan gerak dasar siswa.

Guru pendidikan jasmani harus sadar bahwa jika siswa tidak mempunyai tingkat kebugaran jasmani yang baik maka dimungkinkan akan mempengaruhi prestasi belajar di sekolah. Oleh karena itu sebagai guru pendidikan jasmani yang membimbing siswa di sekolah harus pandai-pandai mengajarkan gaya hidup aktif. Siswa-siswa harus dibiasakan aktif ketika di sekolah baik ketika sebelum masuk sekolah, istirahat, maupun ketika mengikuti pelajaran di sekolah khususnya pelajaran pendidikan jasmani.

Dalam penelitian ini peneliti ingin menerapkan metode pembelajaran yang baru yang bertujuan untuk meningkatkan gerak dasar berbasis pola bermain. Berdasarkan uraian latar belakang diatas menarik bagi peneliti untuk melakukan penelitian tentang "Penerapan Metode Pembelajaran dengan Permainan Bola Gantung Berangka Untuk Meningkatkan Gerak Dasar Anak Usia Dini”.

Pembelajaran adalah suatu aktivitas terjadinya proses belajar mengajar. Aktivitas mengajar dilakukan oleh seorang guru, pendidik, pelatih, instruktur untuk menyampaikan pengetahuan kepada siswa. Menurut Rahyubi (2014) "Pembelajaran merupakan suatu sistem yang terdiri dari berbagai komponen yang saling berhubungan satu dengan yang lain". Komponen tersebut meliputi: tujuan pembelajaran, kurikulum, guru, siswa, materi, metode, media, dan evaluasi.

Menurut Rahyubi (2014) "Pembelajaran motorik adalah suatu proses belajar yang mengarah pada dimensi gerak". Dalam kontek ini, pembelajaran motorik diwujudkan melalui respons-respons muscular (otot) yang diekspresikan dalam gerakan tubuh atau bagian tubuh yang spesifik untuk meningkatkan kualitas gerak tubuh.

Menurut Rahyubi (2014) "Keterampilan merupakan gambaran kemampuan motorik seseorang yang ditunjukan melalui penguasaan suatu gerak". Dalam suatu proses pembelajaran motorik, seorang pembelajar diharapkan mampu menguasai keterampilan motorik, yaitu kemampuan seseorang untuk melalukan suatu tugas gerak secara maksimal sesuai dengan kemampuannya. Keterampilan motorik pada setiap orang berbeda-beda karena banyak hal yang mempengaruhinya antara lain minat atau kemauan, usia, dan pengalaman.

Ketika seseorang mempelajari keterampilan gerak, perubahan nyata yang terjadi adalah meningkatkan mutu keterampilan yang dikuasai. Ini dapat diukur dengan beberapa cara, misalnya dengan melihat skor yang dihasilkan, atau dengan melihat keberhasilan melakukan gerak yang tadinya belum dikuasai. Tetapi yang terjadi sebenarnya bukan hanya itu, sebab 
ada perubahan tambahan atau pengalihan kemampuan yang mendasari penampilan pada penguasaan keterampilan yang baru. Perbaikan kemampuan inilah yang menambah penampilan bertambah baik.

Perkembangan motorik mencerminkan dalam diri individu terjadi perubahan-perubahan dalam bagaimana berinteraksi dengan lingkungan, bertambahnya waktu dan usia perkembangan motorik anak akan tercermin pada bagaimana berinteraksi dengan seseorang dan lingkungannya.

Perubahan-perubahan perkembangan yang positif sangat diharapkan sudah dapat diarahkan sendiri mungkin sejak anak pada usia prasekolah dengan cara memberikan kesempatan bergerak yang banyak, menempatkan pola gerak dasar secara benar dengan pendekatan multilateral, dan pendekatan bermain. Menurut Hendrayana (2003) "Bermain merupakan suatu aktifitas yang dapat dilakukan oleh semua orang, dari anak- anak hingga orang dewasa, tak terkecuali para penyandang cacat. Menurut Rosdiani dalam Ardiyanto (2014) 'Bermain adalah aktivitas yang digunakan untuk mendapatkan kesenangan, keriangan atau kebahagiaan. Maksudnya tidak ada peraturan yang mengikat atau membutuhkan syaratsyarat tertentu. Menurut Sudono dalam Hidayat (2016) "Bermain adalah suatu kegiatan yang dilakukan dengan atau tanpa mempergunakan alat yang menghasilkan pengertian atau memberikan informasi, memberi kesenangan maupun mengembangkan imajinasi pada anak.

Dari beberapa pendapat ahli dapat di simpulkan bahwa bermain adalah suatu kegiatan atau aktifitas yang dapat dilakukan oleh setiap orang yang menimbulkan kesenangan, keceriaan, dan kebahagiaan. Sesuai dunianya sehingga terciptanya perubahan gerak yang dapat mengakibatkan kebugaran fisik anak. Dengan demikian dalam pertumbuhan dan perkembangan anak- anak justru memerlukan peran professional yang tepat pada bidangnya, khususnya berperan aktifnya guru Penjas yang mengerti masalah pertumbuhan dan perkembangah sehingga dapat sejalan dengan pertumbuhan anak secara normal.

Permainan bola gantung berangka adalah permainan yang diciptakan untuk membantu guru TK/RA dalam meningkatkatkan gerak dasar siswa. Dalam permainan tersebut terdapat unsur gerak lari, lompat dan memukul sesuai dengan gerak dasar lokomotor, nonlokomotor dan manipulatif. Tujuan dalam permainan bola gantung berangka ini yaitu sebagai metode pembelajaran baru bagi guru dalam upaya meningkatkan gerak dasar. Dalam permainan bola gantung berangka ini meliputi tiga unsur gerak yaitu berlari, melompat dan memukul. Dengan unsur gerak tersebut diupayakan dapat meningkatkan kemampuan gerak dasar manipulatif siswa. 


\section{Metode}

Metode yang digunakan dalam penelitian ini adalah metode Penelitian Eksperimen. Metode penelitian eksperimen diartikan sebagai metode penelitian yang digunakan untuk mencari pengaruh perlakuan tertentu terhadap yang lain dalam kondisi yang terkendalikan. Lokasi penelitian ini dilaksanakan di Kecamatan Panyingkiran Kabupaten Majalengka, dengan Subjek penelitian ini adalah siswa TK/RA di Kecamatan Panyingkiran Kabupaten Majalengka.

Instrumen dalam penelitian ini adalah lembar tes. Tes digunakan untuk mengukur dan mengetahui kemampuan serta pemahaman siswa setelah model pembelajaran gerak dasar melalui pendekatan pembelajaran latihan berbasis gerak lokomotor dilaksanakan. Bentuknya adalah tes kemampuan gerak dasar. Tabel 1 menunjukkan rekapitulasi aspek yang dinilai dalam tes gerak dasar adalah sebagai berikut.

Tabel 1

Rekapitulasi Hasil Belajar Gerak Dasar

\begin{tabular}{|c|c|c|c|c|c|c|c|c|c|c|c|}
\hline \multirow{2}{*}{ No } & \multirow{2}{*}{$\begin{array}{c}\text { Kode } \\
\text { Sampel }\end{array}$} & \multicolumn{3}{|c|}{ Gerak Dasar } & \multirow{2}{*}{$\begin{array}{c}\text { Jumlah } \\
\text { Nilai }\end{array}$} & \multirow{2}{*}{$\begin{array}{l}\text { Nilai } \\
\text { Akhir }\end{array}$} & \multirow[b]{2}{*}{ SK } & \multirow[b]{2}{*}{$\mathrm{K}$} & \multirow[b]{2}{*}{ S } & \multirow[b]{2}{*}{ B } & \multirow[b]{2}{*}{ SB } \\
\hline & & Jalan & Lari & Lompat & & & & & & & \\
\hline 1. & & & & & & & & & & & \\
\hline 2. & & & & & & & & & & & \\
\hline Dst. & & & & & & & & & & & \\
\hline
\end{tabular}

Untuk menilai setiap aspek gerak dasar lokomotor (jalan, lari dan lompat) berikut adalah instrumen penilaiannya.

Tabel 2

Instrumen Penilaian Praktek Gerak Dasar Jalan

\begin{tabular}{|c|c|c|c|c|c|c|c|c|c|c|c|c|c|c|c|}
\hline \multirow{3}{*}{ No } & \multirow{3}{*}{ Nama siswa } & \multicolumn{12}{|c|}{ Skor Setiap Unsur } & \multirow{3}{*}{ Skor } & \multirow{3}{*}{$\begin{array}{l}\text { Nilai } \\
\text { Akhir }\end{array}$} \\
\hline & & \multicolumn{4}{|c|}{ Irama } & \multicolumn{4}{|c|}{$\begin{array}{c}\text { Gerakan } \\
\text { Kaki }\end{array}$} & \multicolumn{4}{|c|}{$\begin{array}{l}\text { Ayunan } \\
\text { Langkah }\end{array}$} & & \\
\hline & & 1 & 2 & 3 & 4 & 1 & 2 & 3 & 4 & 1 & 2 & 3 & 4 & & \\
\hline 1 & & & & & & & & & & & & & & & \\
\hline 2 & & & & & & & & & & & & & & & \\
\hline Dst & & & & & & & & & & & & & & & \\
\hline
\end{tabular}

Skor Minimum $=1 \times 3$ aspek $=3$

Skor Maksimum $($ Ideal $)=4 \times 3$ aspek $=12$

Nilai Akhir $=\underline{\text { Skor Peroleh }} \times 100$

Deskriptor:

Skor Ideal

Irama,

1. Gerakan yang cepat

2. Terkontrol,

3. Sesuai dengan irama yang dikehendaki.

4. Bisa melakukan dengan irama lambat dan juga bisa cepat seperti gerakan dewasa Bentuk gerakan kedua kaki

1. kaki yang melangkah tidak mengangkang

2. Mendekati garis lurus, 
3. Sudut kedua telapak kaki menyempit.

4. Lutut dan pergelangan kaki bergerak wajar

Ayunan langkah

1. Semakin otomatis,

2. Mampu berjalan seperti gerakan berjalan orang dewasa pada umumnya.

3. Mampu berjalan dengan ayunan kaki

4. Mampu berbelok ke arah yang dikehendaki dengan mudah.

Nilai Penjelasan

1 Satu deskriptor nampak

2 Dua deskriptor nampak

3 Tiga deskriptor nampak

4 Empat deskriptor nampak

Tabel 3

Instrumen Penilaian Praktek Gerak Dasar Lari

\begin{tabular}{|c|c|c|c|c|c|c|c|c|c|c|c|c|c|c|}
\hline \multirow{3}{*}{ No } & \multirow{3}{*}{ Nama } & \multicolumn{11}{|c|}{ Aspek yang diamati } & \multirow{3}{*}{$\begin{array}{l}\text { Jumlah } \\
\text { skor }\end{array}$} & \multirow{3}{*}{$\begin{array}{l}\text { Nilai } \\
\text { akhir }\end{array}$} \\
\hline & & \multicolumn{3}{|c|}{$\begin{array}{c}\text { Gerakan } \\
\text { kaki }\end{array}$} & \multicolumn{3}{|c|}{$\begin{array}{l}\text { Posisi } \\
\text { badan }\end{array}$} & \multicolumn{3}{|c|}{$\begin{array}{c}\text { Gerak } \\
\text { an } \\
\text { lengan }\end{array}$} & \multicolumn{2}{|c|}{$\begin{array}{c}\text { Koordi } \\
\text { nasi }\end{array}$} & & \\
\hline & & 1 & 2 & 3 & 1 & 2 & 3 & 1 & 2 & & 1 & & & \\
\hline 1 & & & & & & & & & & & & & & \\
\hline 2 & & & & & & & & & & & & & & \\
\hline Dst. & & & & & & & & & & & & & & \\
\hline
\end{tabular}

Skor Minimum $=1 \times 4$ aspek $=4$

Skor Maksimum $=3 \times 4$ aspek $=12$

Nilai Akhir $=\underline{\text { Skor Perolehan }} \times 100$

Deskriptor:

$$
\text { Skor Ideal }
$$

Gerakan kaki:

1. Mata kaki dan lutut yang melangkah diluruskan pada saat titik badan bergerak ke depan

2. Kaki yang lain (kaki bebas) ditekan dan bergerak ke depan atas

3. Lutut mencapai tinggi maksimum di depan

Posisi Badan:

1. Titik badan bergerak kedepan saat lutut melangkah

2. Posisi tubuh hampir tegak tanpa membungkuk ke depan atau belakang

3. Memberi keseimbangan antara kaki dan tangan

Posisi tangan:

1. Kedua lengan mengayun memberi keseimbangan gerak terhadap kaki

2. Sikut berada di titik jauh belakang saat lutut lawannye amencapai tinggi maksimun

3. Lengan berayun sedikit menyilang dada dengan sikut membentuk sudut 900 (derajat)

Koordinasi

1. Kombinasi antara angkatan lutut rendah dengan kecepatan lambat

2. Kombinasi antara angkatan lutut sedang dengan kecepatan sedang

3. Kombinasi antara angkatan lutut tinngi dengan kecepatan tercepat

Nilai Penjelasan

1 Satu deskriptor nampak

2 Dua deskriptor nampak

3 Tiga deskriptor nampak 
Tabel 4

Instrumen Penilaian Praktek Gerak Dasar Lompat

\begin{tabular}{|c|c|c|c|c|c|c|c|c|c|c|c|c|c|c|c|c|c|c|c|}
\hline \multirow{3}{*}{ No. } & \multirow{3}{*}{ Nama } & \multicolumn{16}{|c|}{ Aspek yang dinilai } & \multirow{3}{*}{$\begin{array}{c}\text { Jml } \\
\text { Skor }\end{array}$} & \multirow{3}{*}{$\begin{array}{l}\text { Nilai } \\
\text { Akhir }\end{array}$} \\
\hline & & \multicolumn{4}{|c|}{ Awalan } & \multicolumn{4}{|c|}{ Tolakan } & \multicolumn{4}{|c|}{ Melayang } & \multicolumn{4}{|c|}{ Mendarat } & & \\
\hline & & 1 & 2 & & 4 & 1 & & & 4 & 1 & 2 & 3 & 4 & 1 & 2 & 3 & 4 & & \\
\hline 1. & & & & & & & & & & & & & & & & & & & \\
\hline 2. & & & & & & & & & & & & & & & & & & & \\
\hline dst & & & & & & & & & & & & & & & & & & & \\
\hline
\end{tabular}

Skor Minimum $=1 \times 4$ aspek $=4$

Skor Maksimum $=4 \times 4$ aspek $=16$

Nilai Akhir $=\underline{\text { Skor Perolehan }} \times 100$

Skor Ideal

Deskriptor:

Awalan

1. Mengambil jarak awalan tergantung dari kemampuan masing-masing atlet bagi pelompat (sekitar 30-35 meteratau kurang dari ini).

2. Posisi saat berdiri pada titik awalan kaki dapat sejajar atau salah satu kaki ke depan.

3. Pengambilan awalan mulai pelan, kemudian cepat (sprint) yang dipertahankan sampai menjelang bertumpu/menolak.

4. Setelah mencapai kecepatan maksimal, maka kira-kira 3-4 langkah terakhir bertumpu (take off) gerakan lari dilepas begitu saja tanpa mengurangi kecepatan yang telah dicapai sebelumnya.

\section{Tolakan}

1. Saat kaki tumpu menolak pada papan tumpuan

2. Posisi badan lebih digerakan ke belakang

3. Urutan tumpuan kaki menolak pada papan tumpuan, mulai dari tumit, telapak kaki diteruskan pada ujung telapak kaki

4. Gerak mengayun kaki belakang ke depan atas bersamaan dengan kedua lengan

Sikap badan di udara

1. Badan melenting ke belakang

2. Kedua lengan lurus ke atas disamping telinga

3. Kedua kaki hampir rapat di belakang badan

4. Pandangan lurus ke depan

Gerakan Mendarat

1. Dari sikap di udara, kedua lengan diluruskan ke depan

2. Kedua lutut dan badan dibawa kedepan

3. Saat kedua kaki akan menyentuh tempat pendaratan, luruskan kedepan dan mendarat dengan kedua tumit terlebih dahulu

4. Saat kedua kaki mendarat kedua lutut mengeper dan berat badan dibawa kedepan

Nilai Penjelasan

1. Satu deskriptor nampak

2. Dua deskriptor nampak

3. Tiga deskriptor nampak

4. Empat deskriptor nampak 


\section{Hasil Penelitian dan Pembahasan}

Nilai tes awal

\begin{tabular}{|c|c|c|c|c|c|c|c|c|c|c|c|}
\hline \multirow[b]{2}{*}{ No } & \multirow{2}{*}{\begin{tabular}{|l} 
Kode \\
Sampel
\end{tabular}} & \multicolumn{3}{|c|}{ Gerak Dasar } & \multirow{2}{*}{ Jumla } & \multirow{2}{*}{$\begin{array}{l}\text { Rata- } \\
\text { Rata }\end{array}$} & \multirow[b]{2}{*}{ SK } & \multirow[b]{2}{*}{$\mathbf{K}$} & \multirow[b]{2}{*}{$\mathbf{S}$} & \multirow[b]{2}{*}{ B } & \multirow[b]{2}{*}{ SB } \\
\hline & & Jalan & Lari & $\begin{array}{c}\begin{array}{c}\text { Lom } \\
\text { pat }\end{array} \\
\end{array}$ & & & & & & & \\
\hline 1. & \begin{tabular}{|c|} 
Sampel \\
1
\end{tabular} & 83,33 & 66,67 & 75,00 & 225,00 & 75,00 & & & & $\sqrt{ }$ & \\
\hline 2. & \begin{tabular}{|c|} 
Sampel \\
2
\end{tabular} & 75,00 & 66,67 & 75,00 & 216,67 & 72,22 & & & & $\sqrt{ }$ & \\
\hline 3. & \begin{tabular}{|c|} 
Sampel \\
3
\end{tabular} & 66,67 & 75,00 & 66,67 & 208,33 & 69,44 & & & $\sqrt{ }$ & & \\
\hline 4. & \begin{tabular}{|c|} 
Sampel \\
4
\end{tabular} & 50,00 & 66,67 & 66,67 & 183,33 & 61,11 & & & $\sqrt{ }$ & & \\
\hline 5. & \begin{tabular}{|c|} 
Sampel \\
5
\end{tabular} & 83,33 & 75,00 & 66,67 & 225,00 & 75,00 & & & & $\sqrt{ }$ & \\
\hline 6. & $\begin{array}{c}\text { Sampel } \\
6\end{array}$ & 66,67 & 58,33 & 58,33 & 183,33 & 61,11 & & & $\sqrt{ }$ & & \\
\hline 7. & \begin{tabular}{|c|} 
Sampel \\
7
\end{tabular} & 50,00 & 50,00 & 66,67 & 166,67 & 55,56 & & $\sqrt{ }$ & & & \\
\hline 8. & \begin{tabular}{|c|} 
Sampel \\
8
\end{tabular} & 58,33 & 58,33 & 50,00 & 166,67 & 55,56 & & $\sqrt{ }$ & & & \\
\hline 9. & $\begin{array}{c}\text { Sampel } \\
9\end{array}$ & 83,33 & 41,67 & 75,00 & 200,00 & 66,67 & & & $\sqrt{ }$ & & \\
\hline 10. & \begin{tabular}{|c|} 
Sampel \\
10
\end{tabular} & 75,00 & 66,67 & 58,33 & 200,00 & 66,67 & & & $\sqrt{ }$ & & \\
\hline 11. & \begin{tabular}{|c|} 
Sampel \\
11
\end{tabular} & 83,33 & 50,00 & 66,67 & 200,00 & 66,67 & & & $\sqrt{ }$ & & \\
\hline 12. & \begin{tabular}{|c|} 
Sampel \\
12
\end{tabular} & 75,00 & 58,33 & 50,00 & 183,33 & 61,11 & & & $\sqrt{ }$ & & \\
\hline 13. & \begin{tabular}{|c|} 
Sampel \\
13
\end{tabular} & 50,00 & 58,33 & 75,00 & 183,33 & 61,11 & & & $\sqrt{ }$ & & \\
\hline 14. & \begin{tabular}{|c|} 
Sampel \\
14
\end{tabular} & 50,00 & 58,33 & 58,33 & 166,67 & 55,56 & & $\sqrt{ }$ & & & \\
\hline 15. & \begin{tabular}{|c|} 
Sampel \\
15
\end{tabular} & 58,33 & 66,67 & 75,00 & 200,00 & 66,67 & & & $\sqrt{ }$ & & \\
\hline 16. & \begin{tabular}{|c|} 
Sampel \\
16
\end{tabular} & 75,00 & 50,00 & 66,67 & 191,67 & 63,89 & & & $\sqrt{ }$ & & \\
\hline 17. & \begin{tabular}{|c|} 
Sampel \\
17
\end{tabular} & 50,00 & 58,33 & 58,33 & 166,67 & 55,56 & & $\sqrt{ }$ & & & \\
\hline 18. & \begin{tabular}{|c|} 
Sampel \\
18
\end{tabular} & 58,33 & 58,33 & 75,00 & 191,67 & 63,89 & & & $\sqrt{ }$ & & \\
\hline 19. & \begin{tabular}{|c|} 
Sampel \\
19
\end{tabular} & 91,67 & 66,67 & 50,00 & 208,33 & 69,44 & & & $\sqrt{ }$ & & \\
\hline 20. & \begin{tabular}{|c|} 
Sampel \\
20
\end{tabular} & 66,67 & 66,67 & 50,00 & 183,33 & 61,11 & & & $\sqrt{ }$ & & \\
\hline 21. & \begin{tabular}{|c|} 
Sampel \\
21
\end{tabular} & 50,00 & 75,00 & 50,00 & 175,00 & 58,33 & & & $\sqrt{ }$ & & \\
\hline 22. & \begin{tabular}{|c|} 
Sampel \\
22
\end{tabular} & 33,33 & 66,67 & 75,00 & 175,00 & 58,33 & & & $\sqrt{ }$ & & \\
\hline 23. & \begin{tabular}{|c|} 
Sampel \\
23
\end{tabular} & 33,33 & 83,33 & 75,00 & 191,67 & 63,89 & & & $\sqrt{ }$ & & \\
\hline 24. & \begin{tabular}{|c|} 
Sampel \\
24
\end{tabular} & 66,67 & 75,00 & 50,00 & 191,67 & 63,89 & & & $\sqrt{ }$ & & \\
\hline 25. & \begin{tabular}{|c|} 
Sampel \\
25
\end{tabular} & 50,00 & 66,67 & 50,00 & 166,67 & 55,56 & & $\sqrt{ }$ & & & \\
\hline 26. & $\begin{array}{c}\text { Sampel } \\
26\end{array}$ & 58,33 & 75,00 & 83,33 & 216,67 & 72,22 & & & & $\sqrt{ }$ & \\
\hline 27. & \begin{tabular}{|c|} 
Sampel \\
27
\end{tabular} & 91,67 & 91,67 & 66,67 & 250,00 & 83,33 & & & & $\sqrt{ }$ & \\
\hline 28. & \begin{tabular}{|c|} 
Sampel \\
28
\end{tabular} & 66,67 & 91,67 & 83,33 & 241,67 & 80,56 & & & & $\sqrt{ }$ & \\
\hline 29. & \begin{tabular}{|c|} 
Sampel \\
29
\end{tabular} & 50,00 & 75,00 & 75,00 & 200,00 & 66,67 & & & $\sqrt{ }$ & & \\
\hline 30. & $\begin{array}{c}\text { Sampel } \\
30\end{array}$ & 75,00 & 75,00 & 66,67 & 216,67 & 72,22 & & & & $\sqrt{ }$ & \\
\hline \multicolumn{6}{|c|}{ Jumlah } & 1092 & & 5 & 18 & 7 & \\
\hline \multicolumn{6}{|c|}{ Rata-rata/ Persentase } & 64,24 & 0 & $\begin{array}{l}16, \\
67\end{array}$ & $\begin{array}{l}60, \\
00\end{array}$ & $\begin{array}{l}23 \\
33\end{array}$ & 0 \\
\hline
\end{tabular}

Nilai tes akhir

\begin{tabular}{|c|c|c|c|c|c|c|c|c|c|c|c|}
\hline \multirow{2}{*}{$\begin{array}{l}\mathbf{N} \\
\mathbf{o}\end{array}$} & \multirow{2}{*}{$\begin{array}{l}\text { Kode } \\
\text { Sampel }\end{array}$} & \multicolumn{3}{|c|}{ Gerak Dasar } & \multirow{2}{*}{ Jumla } & \multirow{2}{*}{$\begin{array}{c}\text { Rata- } \\
\text { Rata }\end{array}$} & \multirow[b]{2}{*}{ SK } & \multirow[b]{2}{*}{$\mathbf{K}$} & \multirow[b]{2}{*}{$\mathbf{S}$} & \multirow[b]{2}{*}{ B } & \multirow[b]{2}{*}{ SB } \\
\hline & & Jalan & Lari & $\begin{array}{c}\text { Lom } \\
\text { pat }\end{array}$ & & & & & & & \\
\hline 1. & $\begin{array}{c}\text { Sampel } \\
1\end{array}$ & 75,00 & 83,33 & 83,33 & 241,67 & 80,56 & & & & $\sqrt{ }$ & \\
\hline 2. & $\begin{array}{l}\text { Sampel } \\
2\end{array}$ & 75,00 & 75,00 & 83,33 & 233,33 & 77,78 & & & & $\sqrt{ }$ & \\
\hline 3. & $\begin{array}{l}\text { Sampel } \\
3\end{array}$ & 83,33 & 75,00 & 83,33 & 241,67 & 80,56 & & & & $\sqrt{ }$ & \\
\hline 4. & Sampel 4 & 33,33 & 75,00 & 75,00 & 183,33 & 61,11 & & & $\sqrt{ }$ & & \\
\hline 5. & $\begin{array}{l}\text { Sampel } \\
5\end{array}$ & 75,00 & 75,00 & 75,00 & 225,00 & 75,00 & & & & $\sqrt{ }$ & \\
\hline 6. & $\begin{array}{l}\text { Sampel } \\
6\end{array}$ & 75,00 & 75,00 & 83,33 & 233,33 & 77,78 & & & & $\sqrt{ }$ & \\
\hline 7. & $\begin{array}{c}\text { Sampel } \\
7\end{array}$ & 75,00 & 66,67 & 75,00 & 216,67 & 72,22 & & & & $\sqrt{ }$ & \\
\hline 8. & $\begin{array}{c}\text { Sampel } \\
8\end{array}$ & 75,00 & 83,33 & 75,00 & 233,33 & 77,78 & & & & $\sqrt{ }$ & \\
\hline 9. & $\begin{array}{c}\text { Sampel } \\
9\end{array}$ & 75,00 & 75,00 & 66,67 & 216,67 & 72,22 & & & & $\sqrt{ }$ & \\
\hline 10 & $\begin{array}{c}\text { Sampel } \\
10\end{array}$ & 75,00 & 83,33 & 83,33 & 241,67 & 80,56 & & & & $\sqrt{ }$ & \\
\hline 11 & $\begin{array}{c}\text { Sampel } \\
11\end{array}$ & 66,67 & 83,33 & 83,33 & 233,33 & 77,78 & & & & $\sqrt{ }$ & \\
\hline 12 & $\begin{array}{c}\text { Sampel } \\
12\end{array}$ & 75,00 & 83,33 & 83,33 & 241,67 & 80,56 & & & & $\sqrt{ }$ & \\
\hline 13 & $\begin{array}{c}\text { Sampel } \\
13 \\
\end{array}$ & 83,33 & 75,00 & 83,33 & 241,67 & 80,56 & & & & $\sqrt{ }$ & \\
\hline 14 & $\begin{array}{c}\text { Sampel } \\
14 \\
\end{array}$ & 75,00 & 75,00 & 91,67 & 241,67 & 80,56 & & & & $\sqrt{ }$ & \\
\hline 15 & $\begin{array}{l}\text { Sampel } \\
15\end{array}$ & 75,00 & 66,67 & 58,33 & 200,00 & 66,67 & & & $\sqrt{ }$ & & \\
\hline 16 & $\begin{array}{c}\text { Sampel } \\
16\end{array}$ & 75,00 & 75,00 & 83,33 & 233,33 & 77,78 & & & & $\sqrt{ }$ & \\
\hline 17 & $\begin{array}{c}\text { Sampel } \\
17\end{array}$ & 83,33 & 75,00 & 75,00 & 233,33 & 77,78 & & & & $\sqrt{ }$ & \\
\hline 18 & $\begin{array}{c}\text { Sampel } \\
18\end{array}$ & 75,00 & 75,00 & 50,00 & 200,00 & 66,67 & & & $\sqrt{ }$ & & \\
\hline 19 & $\begin{array}{c}\text { Sampel } \\
19\end{array}$ & $\begin{array}{c}100,0 \\
0\end{array}$ & 75,00 & 75,00 & 250,00 & 83,33 & & & & $\sqrt{ }$ & \\
\hline 20 & $\begin{array}{l}\text { Sampel } \\
20\end{array}$ & 75,00 & 75,00 & 75,00 & 225,00 & 75,00 & & & & $\sqrt{ }$ & \\
\hline 21 & $\begin{array}{l}\text { Sampel } \\
21\end{array}$ & 75,00 & 75,00 & 58,33 & 208,33 & 69,44 & & & $\sqrt{ }$ & & \\
\hline 22 & $\begin{array}{c}\text { Sampel } \\
22\end{array}$ & 83,33 & 75,00 & 75,00 & 233,33 & 77,78 & & & & $\sqrt{ }$ & \\
\hline 23 & $\begin{array}{c}\text { Sampel } \\
23\end{array}$ & 75,00 & 58,33 & 75,00 & 208,33 & 69,44 & & & $\sqrt{ }$ & & \\
\hline 24 & $\begin{array}{c}\text { Sampel } \\
24 \\
\end{array}$ & 75,00 & 75,00 & 83,33 & 233,33 & 77,78 & & & & $\sqrt{ }$ & \\
\hline 25 & $\begin{array}{c}\text { Sampel } \\
25\end{array}$ & 75,00 & 66,67 & 66,67 & 208,33 & 69,44 & & & $\sqrt{ }$ & & \\
\hline 26 & $\begin{array}{c}\text { Sampel } \\
26\end{array}$ & 75,00 & 75,00 & 75,00 & 225,00 & 75,00 & & & & $\sqrt{ }$ & \\
\hline 27 & $\begin{array}{c}\text { Sampel } \\
27 \\
\end{array}$ & $\begin{array}{c}100,0 \\
0\end{array}$ & 91,67 & 75,00 & 266,67 & 88,89 & & & & & $\sqrt{ }$ \\
\hline 28 & $\begin{array}{c}\text { Sampel } \\
28\end{array}$ & 75,00 & 91,67 & 83,33 & 250,00 & 83,33 & & & & $\sqrt{ }$ & \\
\hline 29 & $\begin{array}{c}\text { Sampel } \\
29 \\
\end{array}$ & 75,00 & 75,00 & 75,00 & 225,00 & 75,00 & & & & $\sqrt{ }$ & \\
\hline 30 & $\begin{array}{c}\text { Sampel } \\
30\end{array}$ & 75,00 & 75,00 & 75,00 & 225,00 & 75,00 & & & & $\sqrt{ }$ & \\
\hline \multicolumn{6}{|c|}{ Jumlah } & 1092 & & & 6 & 23 & 1 \\
\hline \multicolumn{6}{|c|}{ Rata-rata/ Persentase } & 64,24 & 0 & & $\begin{array}{l}20, \\
00\end{array}$ & \begin{tabular}{|l|}
76, \\
67
\end{tabular} & $\begin{array}{c}3,3 \\
3\end{array}$ \\
\hline
\end{tabular}

Setelah rata-rata dan simpangan baku serta variansi diperoleh, Langkah selanjutnya adalah menghitung normalitas dari kelompok sampel. Pengujian normalitas yang penulis gunakan adalah uji normalitas Lilliefors. Hasil penghitungannya adalah sebagai berikut: 
Tabel 6

Hasil Uji Normalitas Tes Awal dan Tes Akhir

\begin{tabular}{|c|c|c|c|c|}
\hline Indikator Tes & Tes & Lo & Ltabel & Ket. \\
\hline Kemampuan Gerak & Tes Awal & 0,151 & 0,220 & Normal \\
\hline
\end{tabular}

Langkah selanjutnya adalah menghitung signifikansi kemampuan gerak dasar kelompok sampel. Pendekatan statistik yang digunakan adalah distribusi student dengan kriteria pengujiannya adalah terima Ho jika $-\mathrm{t} 1-1 / 2 \alpha<\mathrm{t}<\mathrm{t} 1-1 / 2 \alpha$ di dapat dari daftar distribusi dengan $\mathrm{dk}=(\mathrm{n} 1+\mathrm{n} 2-2)$ dan peluang $(1-1 / 2 \alpha)$. Untuk harga lainnya Ho ditolak. Hasil penghitungan adalah sebagai berikut:

Tabel 8

Rekapitulasi Hasil Uji Signifikansi Peningkatan Kemampuan Gerak Dasar dari Kelompok Sampel

\begin{tabular}{|c|c|c|c|}
\hline Tes & Thitung & Ttabel & Ket \\
\hline Kemampuan Gerak Dasar & $\mathbf{0 , 2 7}$ & 2,05 & Signifikan \\
\hline
\end{tabular}

Berdasarkan hasil penghitungan yang dilakukan peneliti diperoleh nilai Thitung sebesar 0.27 dan Ttabel sebesar 2,05. maka dari hasil penghitungan tersebut jelaslah bahwa hipotesis dalam penelitian ini adalah sebagai berikut: Terdapat pengaruh yang efektif dari penerapan permainan bola gantung berangka terhadap kemampuan gerak dasar anak usia dini di Kecamatan Panyingkiran Kabupaten Majalengka.. Dengan kata lain setelah melihat hasil penghitungan tersebut, maka dengan demikian hipotesis yang penulis ajukan diterima. Berdasarkan hasil analisis data dalam penelitian ini, bahwa penerapan permainan bola gantung berangka dapat meningkatkan kemampuan gerak dasar anak usia dini, yang telah mencapai kategori baik.

Hal tersebut sejalan dengan pernyataan Mithayani (2012) 'kemampuan gerak merupakan kemampuan seseorang dalam melakukan gerakkan, melalui aktifitas bermain gerak dasar anak akan berkembang, kemudian diikuti dengan adanya perkembangan kemampuan gerak anak'. Aktivitas bermain pada anak banyak dilakukan dengan aktifitas jasmani. Aktifitas jasmani sangat penting untuk pertumbuhan anak. Dengan bergerak tanpa disadari anak-anak telah berlatih dan hal-hal itu tentunya akan meningkatkan gerak dasar mereka. Dasar gerak akan lebih baik karena kekeuatan otot, kelenturan, daya tahan otot, dan daya tahan kardiovaskular menjadi lebih baik.

Lingkungan harus diatur dan peralatan yang dipilih sesuai dengan tujuan tugas dan ukuran, kekuatan dan kemampuan anak (Gagen \& Getchell, 2006). Secara umum, guru 
TK/RA mungkin tidak memiliki pendidikan dan pengalaman yang cukup dalam mengajarkan pendidikan jasmani kepada anak-anak untuk menginstruksikan kemampuan gerak dasar yang sesuai untuk memenuhi kebutuhan perkembangan motorik anak-anak. Penelitian sebelumnya yang dilakukan oleh Gagen \& Getchell, (2006); Goodway et al., (2003); Zachopoulou et al., (2004), menunjukkan bahwa: "perlunya pendidik fisik profesional jika anak-anak berlatih kemampuan gerak dasar serbaguna dan menunjukkan peningkatan yang signifikan”.

Orang dewasa harus mendorong anak-anak untuk menghabiskan beberapa jam di luar rumah dan di lingkungan fisik yang serupa dan serba guna setiap hari untuk mempromosikan pengembangan keterampilan motorik mereka dengan cara bermain fisik (Timmons et al., 2007). Sesuai dengan pendapat tersebut, maka dalam mengembangkan kemampuan gerak dasar anak dapat menggunakan metode bermain.

Hasil penelitian ini dapat digunakan dalam pembelajaran penjas untuk meningkatkan gerak dasar siswa. Sejalan dengan tujuan pembelajaran motorik bahwa pembelajaran atau pembelajaran gerak merupakan hal yang penting dalam kehidupan manusia, bahkan disadari atau tidak pembelajaran motorik telah menyatu dengan kehidupan manusia itu sendiri. Dengan pembelajaran yang terarah, terancang, dan terpola dengan baik, seseorang diharapkan mampu menguasai pembelajaran motorik secara memuaskan dan berdaya guna. Dari pembelajaran motorik ini diharapkan muncul salah satu produk dan hasil dari pembelajaran yang telah menguasai keterampilan motorik secara baik dan mumpuni (bisa disebut juga penampilan terampil) setidaknya telah punya bekal yang sangat penting dan berguna untuk menapaki kehidupan menuju hari depan yang lebih baik.

Keterampilan motorik bisa berguna bagi kehidupan dan karir seseorang diberbagai lapangan kehidupan yang berfaedah sesuai dengan bakat, kecenderungan, dan potensinya. Penguasaan keterampilan motorik yang baik bisa didayagunakan untuk meraih prestasi yang gemilang dibidang olahraga, seni, musik, dunia kerja yang beragam, berbagai potensi, dan masih banyak lainnya.

\section{Kesimpulan}

Berdasarkan hasil analisis data dalam penelitian ini, bahwa penerapan permainan bola gantung berangka dapat meningkatkan kemampuan gerak dasar anak usia dini, yang telah mencapai kategori baik. Terdapat pengaruh yang efektif dari penerapan permainan bola gantung berangka terhadap kemampuan gerak dasar anak usia dini di Kecamatan Panyingkiran Kabupaten Majalengka. Dengan kata lain setelah melihat hasil penghitungan tersebut, maka dengan demikian hipotesis yang penulis ajukan diterima. 


\section{Daftar Pustaka}

Ambara, P. D., dkk. (2014). Asesmen Anak Usia Dini. Yogyakarta. Graha Ilmu.

Asmawati.(2014). Perencanaan Pembelajaran PAUD. Bandung. PT. Remaja Rosdakarya Offset.

Gagen, L.M., \& Getchell, N. (2006). Using 'constraints' to design developmentally appropriate movement activities for early childhood. Early Childhood Education Journal, 34(3), 227 232.

Goodway, J.D., Crowe, H., \& Ward, P. (2003). Effects of motor skill instruction on fundamental motor skill development. Adapted Physical Activity Quarterly, 20, 298-314.

Hendrayana, Y. (2003). Pembelajaran Permainan Dasar. Departemen Pendidikan Nasional Direktorat Jendral Pendidikan Dasar dan Menengah Direktorat Pendidikan Luar Biasa.

Hidayat. (2016). Teori Bermain Dan Permainan Tradisional. Modul. Bekasi. Samadairu.

Lutan, R., dkk. (2007). Evaluasi Pendidikan Jasmani. Modul. Bandung. Jurusan Pendidikan Kepelatihan Fakultas Pendidikan Olahraga Dan Kesehatan Universitas Pendidikan Indonesia.

Mahendra, A. (2007). Teori Mengajar Motorik. Modul. Bandung : FPOK UPI

Maulana, A. N. (2015). Pengembangan Model Pembelajaran Hop Dalam Lompat Jangkit Pada Siswa kela VII Di SMP Negeri I Bango Dua Kabupaten Indramayu. (Skripsi). Majalengka. FKIP UNMA.

Muhamad, N \& Uno, B. H. 2011. Belajar Dan Pembelajaran PAIKEM. Jakarta. Bumi Aksara

Nurbaeti, Y. (2015). Upaya Mengembangkan Kemandirian Anak Melalui permainan Properti Pada Kelompok $\quad B \quad T K \quad$ Kartika XI-33 Majalengka. (Skripsi). Majalengka. FKIP UNMA

Rahyubi, H. (2014). Teori-Teori Belajar Dan Aplikasi Pembelajaran Motorik. Bandung. Nusa Media.

Rosdiani, D. (2012). Model Pembelajaran Langsung Dalam Penjas Dan Kesehatan. Bandung. Alfabeta.

Rosdiani, Dini. (2013). Perencanaan Pembelajaran Dalam Penjas Dan Kesehatan. Bandung. Alfabeta.

S. Iivonen, A. Sääkslahti \& K. Nissinen (2011) The development of fundamental motor skills of fourto five-year-old preschool children and the effects of a preschool physical education curriculum, Early Child Development and Care, 181:3, 335-343,

Sugiono. (2015). Metode Penelitian Kuantitatif, Kualitatif R\&D. Bandung. CV Alfabeta.

Timmons, B.W., Naylor, P.-J., \& Pfeiffer, K. (2007). Physical activity for preschool children: How much and how? Applied Physiology Nutrition and Metabolism, 32(Suppl. 2E), S122-S134.

Sumber Lain:

Pratomo, Budi, Tataq. (2010).https://eprints.uns.ac.id/1560/1/558-1411-1-SM.pdf.(30, Oktober 2016. 18:30). Nugraha, Panji, dkk.(2012).http://journal.unnes.ac.id/sju/index.php/peshr.(02.Nev ember 2016.14:00)

https://mithayani.wordpress.com/2012/06/05/gerak-dasar-dalam-pendidikanNovember 2016. 13.45)

http://file.upi.edu/Direktori/FIP/JUR._PEND._LUAR_BIASA/195208231978031AMAD_WIDYA/ringkasan.pdf (02, November 2016. 13:50) 